\title{
THE WOLVES ARE BACK! LOCAL ATTITUDES TOWARDS THE RECENTLY RE-POPULATED GREY WOLF AND WOLF MANAGEMENT IN BÜKK NATIONAL PARK, HUNGARY
}

\author{
Brandon P. Anthony and Katalin Tarr \\ Department of Environmental Sciences \& Policy, Central European University \\ H-1051 Budapest, Nádor u. 9, Hungary \\ E-mails: anthonyb@ceu.edu; https://orcid.org/0000-0001-7033-4936 \\ katalintarr@yahoo.co.nz; https://orcid.org/0000-0003-1049-1061
}

\begin{abstract}
Parallel to trends in North America and elsewhere in Europe, the number of large carnivores is slowly increasing in Hungary, including within the Bükk National Park (BNP). After almost a century of absence, the wolf (Canis lupus) re-entered the BNP in 2010, and human-wolf conflicts of livestock depredation and competition for wild game immediately followed. Local acceptance is a key factor in successful large carnivore conservation and coexistence. Utilizing a household questionnaire administered in 3 local villages and semistructured interviews with key stakeholders, in this exploratory study we assessed local attitudes and the suite of demographic, socio-economic, and cultural variables which shape them, and their implications towards wolf management in BNP. Our results are similar to global trends, namely attitudes are varied towards institutions responsible for wolf management, and towards wolves themselves with Wolf Attitude Index values ranging from -20 to $22(\mathrm{M}=0.59, \mathrm{SD}=10.874, \mathrm{n}=51)$ reflecting positive, neutral and negative sentiments. We demonstrate that attitudes towards wolves are largely determined by communication channels concerning wolf knowledge and hunting orientation. These factors are discussed, along with recommendations towards expanded research and enhanced coexistence.
\end{abstract}

Keywords: Bükk National Park, Canis lupus, human-wildlife conflict, Hungary, wolf conservation

\section{INTRODUCTION}

In Hungary, similarly to elsewhere in Europe, the numbers of grey wolf (Canis lupus) radically diminished by the end of the 19th century, and was subsequently extirpated from the country. This situation continued until the end of the 1980s and, since it was not listed as a protected animal, the shooting of lone individuals was permitted, moreover, encouraged (SzEMETHY et al. 2004). However, akin to other areas of Europe (BARKHAM 2017, ChAPron et al. 2014, Herzog 2018), the numbers of wolves in Hungary started a spontaneous, capricious, but growing trend since the 1990s (Heltai 2002, Szemethy et al. 2004). Wolves in Europe now number c. 17,000 (of which 13,000 to 14,000 are within the EU) in nine populations (LCIE 2019). The legal status of wolves in the European Union is directly specified in the Habitats Directive (92/43/EEC) where by default wolf populations are listed under Annexes II and IV, although there are 
some exceptions and derogations (KACZENSKY et al. 2013). In Hungary, wolves were classified as a 'protected' species in 1993, and then as 'strictly protected' in 2001 (Szemethy et al. 2004). The last published estimate of wolves in Hungary is limited to about 10-25 individuals (KACZENSKY et al. 2013).

In Bükk National Park (BNP), located in north-east Hungary, and constituting the southernmost part of the north-western Carpathians, the continuous presence of grey wolf has been recognized since 2010, when an injured wolf was observed, and human-wolf conflicts immediately ensued. In subsequent years wolves repeatedly depredated on livestock (or were accused of depredations caused by dogs), and the institution largely responsible for wild game management in BNP issued a damage compensation complaint towards BNP Directorate (hereafter BNPD) for wolf damage to wild game, and for which a wolf was also illegally shot (BNPD 2011, 2014, 2015, 2016). The proof of not only wolf presence, but later wolf reproduction, in the park received widespread media coverage (BNPD 2014, 2015), and fostered the public promotion of large carnivores and the ecological services they provide by the BNPD (BNPD 2016). Thus, the spontaneous re-appearance of wolves in BNP immediately created a divergence of perceptions: one identifying wolves as depredators of livestock and competitors for wild game, and another, applauding wolf conservation.

In general, wolves generate strong feelings that vary widely among different cultural groups, producing both passionate supporters and enemies (Boitani 1995, Primm \& Clark 1996, Linnell 2013). On one hand, the conservation of wolves has increasing cultural support, due to their aesthetic and cultural value (Sillero-Zubiri et al. 2004, Mech \& Boitani 2010, Linnell 2013), as well as their increasingly appreciated role as apex predators (MecH 2017), although this has purportedly often been exaggerated and lacks ample evidence (Allen et al. 2017).

Conversely, from a human-wildlife conflict perspective, wolves are considered 'problematic' animals, chiefly due to the material loss caused by depredation on (often unattended) livestock (Russo et al. 2016), and competition for wild game, whether real or perceived. Also, commonly, the perceived fear and risk of wolf attacks on humans is high, especially in areas where wolves have re-appeared after a long period of absence (LinNell 2013). Wolves are less tolerated by human populations than other large carnivores, for example, the coverage of wolf attacks in the media can be thirty-fold higher compared to bears, and often wolves are held responsible for more damage than other carnivores even if objective analysis proves otherwise (RIGG et al. 2011, LiNNELL 2013, Fernández-Gil et al. 2016). Furthermore, misinformation and rumours that exaggerate or downplay the risks that wolves pose, or that imply that wolves have been secretly and illegally reintroduced (as opposed to have 
recolonized an area naturally), is common not only in society, but in higher levels of decision-making as well (SKOGEN \& KRANGE 2003).

The impact of human-wolf conflicts is not always financial in nature: e.g. in the case of livestock depredation, the loss is also perceived as indirect evidence for a lack of respect from society (usually in favour of large carnivores) towards the farming profession, and such incidents are being either greatly exaggerated or utterly down-played by various actors (LiNNELL 2013). Frustration toward authorities and the lack of adequate management actions also generate negative attitudes towards wolves (POHJA-MYKRA \& KURKI 2014) and, according to HeberLeIN (2012), for farmers, the wolf can be a symbol of urban society's dominance, embodying alien values about the use of animals and natural resources. Thus, large carnivores can become surrogates of other, general symptoms of a changing society such as rural depopulation, separation of urban and conservative rural values, decline of traditional rural economic activities and the concomitant physical transformation of landscapes, or new legislation (e.g. species protection and land use restrictions) that originate from 'far away' levels that many rural people feel powerless to influence (Linnell 2013, Pohja-Mykra \& Kurki 2014, Hojberg et al. 2016). This low level of tolerance appears to be greater in areas where the species return after long periods of absence, and in areas where protection is imposed on previously hunted populations (LiNNELL 2013).

While a number of both rural and urban publics support the underlying principle of large carnivore conservation in Europe (LinNELL 2013, WECHSELBERGER et al. 2005), some analyses reveal that particular attributes can be strong predictors of increased tolerance (JoHANSSON \& KARLSSON 2011), including higher education, younger age, being male, and urban residence (Naughton-Treves et al. 2003, Pohja-Mykra \& Kurki 2014).

BNP is located in a rural area in the socio-economically least advantageous region of Hungary, and has been impaired by high rates of unemployment, poverty, and emigration of active age groups from the region to more prosperous regions (RoAf et al. 2014, KSH 2016, AnON 2017). Therefore, both financial and non-financial attributes of human-wolf conflicts are likely to have a significant impact on local residents. FriTTs et al. (2003) highlight that in such cases where wolves are returning after extended periods of absence, local people often turn to government and local authorities at the slightest appearance of conflict and, if unresolved, intolerance escalates towards both the predators themselves and often towards the institutions responsible for managing wildlife. As wolves are slowly gaining a foothold in BNP, a space for both ecological and social research is nascent, particularly on how local communities respond to their presence. This research is critical, as large carnivores are vulnerable and often controversial taxa, and any poorly designed management intervention could rapidly destroy the success of their long term survival (DALERUm et 
al. 2009, Herzog 2018, Mattson 2004). To our knowledge, no study has been carried out of this nature in Hungary, thus the main objectives of our trial study were to (i) assess and describe the direction and strength of attitudes towards wolves and wolf management, (ii) identify which factors significantly contribute to these attitudes, and (iii) identify key challenges of wolf conservation and possible solutions by which they can be addressed.

\section{METHODS}

In order to carry out this exploratory study, we utilized a mixed method approach including a face-to-face questionnaire on a random sample of households, and semi-structured interviews with an initial suite of key stakeholders.

\section{Study area}

BNP was established in 1977 as the third national park in Hungary, and now covers 43,168.8 ha (BNPD 2017a) as part of the Natura 2000 network. The park comprises $94.27 \%$ forest, $3.35 \%$ grassland (meadow and pasture), $1.95 \%$ withdrawn from cultivation, $0.42 \%$ arable land, and $0.01 \%$ vineyards and orchards. BNP is situated in two counties, the larger part $(65 \%)$ in Borsod-Abaúj-Zemplén County, while the smaller $(35 \%)$ in Heves County. Approximately $97.7 \%$ of the park is state owned, with the Egererdo" Forestry Company managing the western side and the Északerdő Forestry Company the eastern side. Only $2.5 \%$ of the area is directly managed by the BNPD, the larger entity which oversees nature conservation (including wolf management) over a wider operational area in this region of Hungary (BNPD 2017a, Мıно́к et al. 2017).

Although there are a number of villages that are located within/adjacent to BNP, three were selected for this initial study (Szilvásvárad, Nagyvisnyó, Répáshuta; Fig. 1) as these were determined by BNP staff to be the most impacted by BNP wildlife management. Szilvásvárad is the largest in our sample (Table 1) and touristic in nature, being a point from where many visitors approach BNP. There are several hotels and guesthouses in the village, livestock breeding is not prevalent, and the village is well connected by public transport to a nearby larger urban center (Eger). Nagyvisnyó is a smaller settlement about $5 \mathrm{~km}$ from Szilvásvárad, having a rural profile, with negligible tourism. Répáshuta is a relatively small isolated village within BNP, with chief activities being forestry, hunting, and logging.

\section{Questionnaire}

The questionnaire had 45 items (Supplementary Material), organized into three sections based largely on pre-defined attributes. The first section constituted closed questions on demographic and socio-economic factors. The second section contained both closed and open-ended questions on the respondent's relationship to BNPD, knowledge on wolves and wolf management, and accounts of direct experience with wolves. The third section comprised Likert scale statements on attitudes towards wolves and wolf management.

The questionnaire was administered to 51 randomly selected households $(\mathrm{CI}=11.5$, $\mathrm{CL}=90 \%$; Table 1) from April to May 2017. Only adult persons were surveyed, on a voluntary basis with informed consent, adhering to our research ethics protocol. Random sam- 
Table 1. Population and sample of selected villages (data source: KSH 2017a, 2017b).

\begin{tabular}{lccc}
\hline Village & Population & Households & Sampled households (n /\%) \\
\hline Répáshuta & 445 & 176 & 12 / 6.82 \\
Nagyvisnyó & 1001 & 443 & $14 / 3.16$ \\
Szilvásvárad & 1684 & 696 & $25 / 3.59$ \\
\hline Total & 3130 & 1315 & $51 / 3.88$ \\
\hline
\end{tabular}

pling was executed using a directory of households obtained from the municipality, assigning a serial number to each household, and then selecting the households with a random number generator tool. If the selected household turned out to be uninhabited (e.g. the house was empty, functions as a weekend house/ tourist guesthouse), the "left-two" rule was applied, i.e. the second house to the left side was targeted to replace the uninhabited house. The same rule was applied if nobody was at home after two survey attempts on different days.

Although our original sample size was 98, many households were found to be uninhabited (either abandoned, for sale, or only used as summer cottages) which, due to time constraints, reduced our final sample size. Although this is a potential limitation of our study, due to the perceived homogenous nature of small communities, a weaker confidence interval is theoretically acceptable in social surveys (SснUтт 2016), and our qualitative data provides complementary information. Also, research has proven that the household unit rather than individuals may be a critical element to consider wildlife value orientations, which shape attitude and behaviour toward wildlife (CLARK et al. 2017). Second, the fact

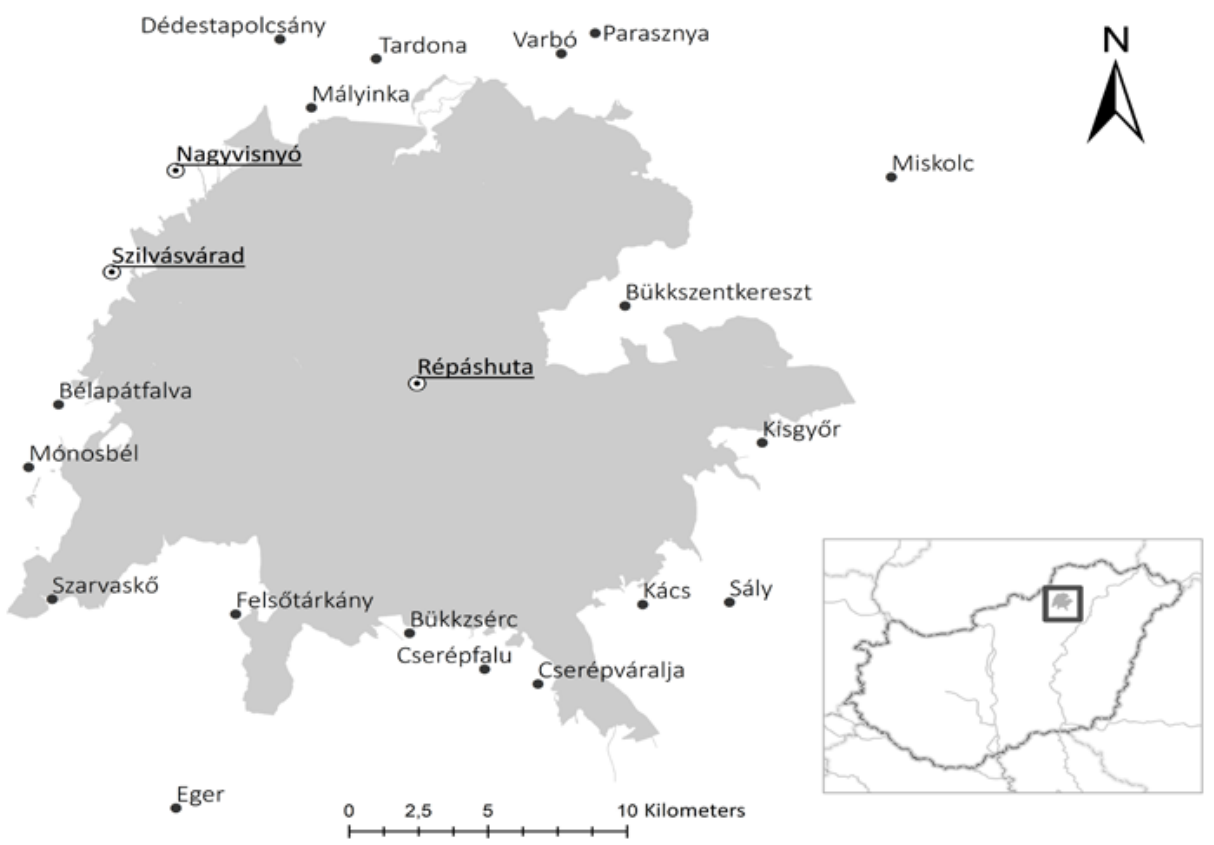

Fig. 1. The location of BNP in Hungary (inset) and study villages (underlined) 
that only explicit attitudes were tested is a limitation, e.g., in smaller and closer communities, group pressure and strong normative pressures can influence the expression of explicit attitudes (РонјA-MүкRA \& KURкі 2014). These limitations were carefully considered in the analysis of the results, as we do not generalize beyond the sampled households.

\section{Analyses}

We summarized demographic and socio-economic variables using univariate statistics available in SPSS version 22.0 (IBM CoRP. 2013), and according to variable type. Where distributions are not normal, non-parametric tests are used. Correlation analyses between variables was conducted according to variable type, with alpha set at .05.

Community attitudes towards wolves and wolf management were measured by responses to 14 related statements with five possible responses ( $1=$ fully agree, $2=$ somewhat agree, 3 = neither agree nor disagree, $4=$ somewhat disagree, $5=$ fully disagree). Four statements were intentionally reversed so final scores on these statements were then converted back to match the direction of attitude with other statements. Individual responses to the statements were then converted to numeric values $(-2=$ very negative, $-1=$ somewhat negative, 0 = neutral, 1 = somewhat positive, 2 = very positive) and summed to create a single Wolf Attitude Index (WAI), i.e. a composite interval level scale of our Likert-type statements. Although Likert-type scales are technically ordinal scales, they can be treated as continuous variables and normal theory statistics can be utilized, particularly when there are 5 or more categories (Zumbo \& Zimmerman 1993). Cronbach's alpha, an index of reliability of a set of items measuring a single uni-dimensional latent construct (CRONвасн 1951), was utilized on the attitude index to eliminate items. Correlation analyses were carried out to identify which variables were significantly correlated with WAI score, and Factorial ANOVA was eventually conducted to measure main and interaction effects of categorical independent variables on WAI score.

The respondents' answers to open-ended questions and other comments were coded based on the major observed human-wolf relation concepts (dis/trust in authorities, fear, economic disadvantage due to wolf conflicts, wolves' role in ecosystem maintenance, etc.), and were used as additional qualitative results to identify local characteristics, and to assist interpretation of quantitative data.

\section{Semi-structured interviews with key informants}

To better understand the diversity of local socio-economic characteristics and motivations in terms of nature conservation and wolf management, we interviewed an initial set of six key informants including two livestock breeders, a BNPD employee, guesthouse owner, wild game manager, and a local educator. The interview questions targeted knowledge and opinions on: wolves in general, and in BNP; impact of wolves on wildlife, human safety, livestock, and the ecosystem; eventual wolf-human conflict events; and wolf management in BNP.

The content of our semi-structured interviews with stakeholders were analysed utilizing content analysis according to emergent themes (KRIPPENDORFF 2004), in order to discern local characteristics, identify unknown and unexpected factors and causalities, and recount the situation from the respondents' point of view (FLICK et al. 2010). Also, qualitative analysis complemented the questionnaire results through differentiation and intensification. 


\section{RESULTS}

\section{Socio-demographic profile}

Our sample consisted of 32 female and 19 male respondents, with ages ranging from 22 to $94(\mathrm{M}=59.4, \mathrm{SD}=17.67)$. Household size was relatively small, ranging from one to six (median $=2.00, \mathrm{n}=51$ ), with a large majority of respondents $(84.3 \%)$ having lived in their village for $>30$ years. Most respondents' highest level of education was secondary school in all villages $(74.5 \%)$, reflecting the age composition, as there is a significant, inverse relationship between age and level of education (Spearman's rho $=-0.447, \mathrm{n}=51, \mathrm{p}<0.01$ ). Most respondents are retired (51\%), and none claimed to be unemployed, although a few respondents indicated they are informally employed or only employed in seasonal jobs. One third of our respondents reported to own livestock, which predominantly consist of poultry (31.4\%; all three villages), rabbits (9.8\%; all three villages), pigs (5.9\%; Nagyvisnyó and Répáshuta) and horses (4.0\%; Répáshuta and Szilvásvárad).

\section{Relationship to BNPD}

Although $18.4 \%$ of our respondents indicated that they never visit BNP, one half noted that they venture into the park at least monthly for a variety of reasons (especially those from Répáshuta, 90.9\%). Reasons for visitation includes hiking $(70.6 \%)$, collecting mushrooms and/or firewood (51.0\%), sport $(15.7 \%)$, employment $(13.7 \%)$, and to hunt $(3.9 \%)$. About one in five of our respondents indicated that they are, or had been, working in a forestry-related job, with most of these being from Répáshuta.

In the course of our surveys, seven respondents (14\%) voiced their frustration about some aspects of management activities in BNP, which is linked to restriction on natural resource use (especially firewood collection), limitation of seasonal jobs in logging, damage caused by wild game, or to perceived frustrations caused by modern forestry practices (attributing pest damages to leaving dead wood in the forest).

"Because of the environmentalists we are not allowed to collect firewood anymore, although it was possible for many decades. There are too many foxes and eagles, killing the hens. It used to be different earlier." / retired male, Nagyvisnyó /

"There are no jobs because of BNP. They do not allow logging anymore. The number of wild game has decreased, hunters are disappearing. There are lots of bugs in the yard and house, because dead wood is left in the forest." / middle-aged forestry employee, Répáshuta /

"I am outraged by this new style of forestry. Local people used to always do some foraging - now it is illegal to even take a bunch of convallaria [Convollaria 
majalis; Lily-of-the-valley]. They are not planting saplings anymore, they are just leaving everything without taking care. They only focus on protected plants, not on the common plants. The meadows are not reaped anymore, they have become wild and many plants went extinct. The forest must be kept in order." / retired female, Szilvásvárad /

These spontaneous and voluntary comments suggest that nature (and by default wolf) conservation may be perceived as surrogates of other socioeconomic issues, such as lack of trust in authorities, livelihood restriction, or misunderstanding concerning management practices. This sentiment was confirmed by both the BNPD employee and educator we interviewed, and highlighted by one survey respondent:

"Wolf management should be the task of God only. We should spend money on hospitals, not on wolves. My daughter's dog was killed by a neighbour, but the police did nothing - but if someone kills a wolf, they will have to go to prison. This is not fair ... Wolves should be all killed or taken away to a zoo." / female pensioner, Nagyvisnyó /

\section{Experience with wolves}

Six of our respondents $(11.8 \%)$ claimed that they had seen a wolf in BNP. Details of these observations indicate that all encounters were from a distance (at least $50 \mathrm{~m}$ ), and that the wolf had subsequently ran away. Three additional respondents indicated they have observed wolf tracks, including two who discovered the remains of prey predated by wolves (roe deer, Capreolus capreolus). However, $52.9 \%$ could recite stories from others' wolf encounters.

None of our survey respondents stated that they had lost livestock to wolves (presumably because most livestock raised are poultry; cf LANszKI et al. 2012), although $49 \%$ provided details of an incident elsewhere concerning wolf depredation on livestock. All narratives involved sheep attacks, with one indicating an attack on a young foal, and another on cattle. About one in five of our respondents had also heard stories about wolves being shot, with time periods ranging from 2-25 years ago. However, both of the livestock breeders who were interviewed had lost sheep to wolves (one showed photographic evidence), and expressed neutral to extremely negative attitudes towards wolves, depending on how dependent animal husbandry was to their livelihood.

\section{Wolves and wolf management}

Respondents indicated from where they had gained information about wolves, being allowed to state multiple sources. The most frequent $(52.9 \%)$ medium mentioned was TV, followed by family/friends (31.4\%), books (31.4\%), brochures $(29.4 \%)$, internet $(23.5 \%)$, school $(17.6 \%)$, and finally sign boards 
(3.9\%). In addition, nine respondents mentioned other sources including movies, BNPD personnel, and the presentation of a wolf trainer with live wolves in Szilvásvárad. Almost half (43.1\%) of our respondents had heard stories from older villagers that wolves had once roamed the BNP area. These stories include accounts of wolves allegedly attacking a small child in a nearby village some 80-90 years ago, and the last wolf being shot in 1919 in Bélapátfalva.

Managing for increasing wolf numbers by BNPD was also perceived in a negative light by some of our interviewees. Both the wild game management professional and a guesthouse owner expressed frustration that, because wolves have 'significantly' decreased game populations and/or altered their predictability, economic losses have resulted because less hunters are coming to the area.

To elicit knowledge concerning wolf biology and behaviour, respondents were asked to estimate the normal pack size of wolves, and whether dogs and wolves could produce fertile offspring. According to Месн and Bortani (2003), pack sizes range from 4 to 12, which the vast majority of respondents (81\%) correctly estimated, although respondent estimates ranged from 1-3 to as high as $21-30$. Moreover, two-thirds correctly stated that wolves and dogs could successfully hybridize (Lescureux \& LiNNELL 2014), including 78.1\% of those who correctly estimated pack size. Respondents were also requested to provide an estimate of the current number of wolves in BNP, and indicate whether they would prefer that number to decrease, remain the same, or increase. According to BNPD rangers, the current number is believed to be

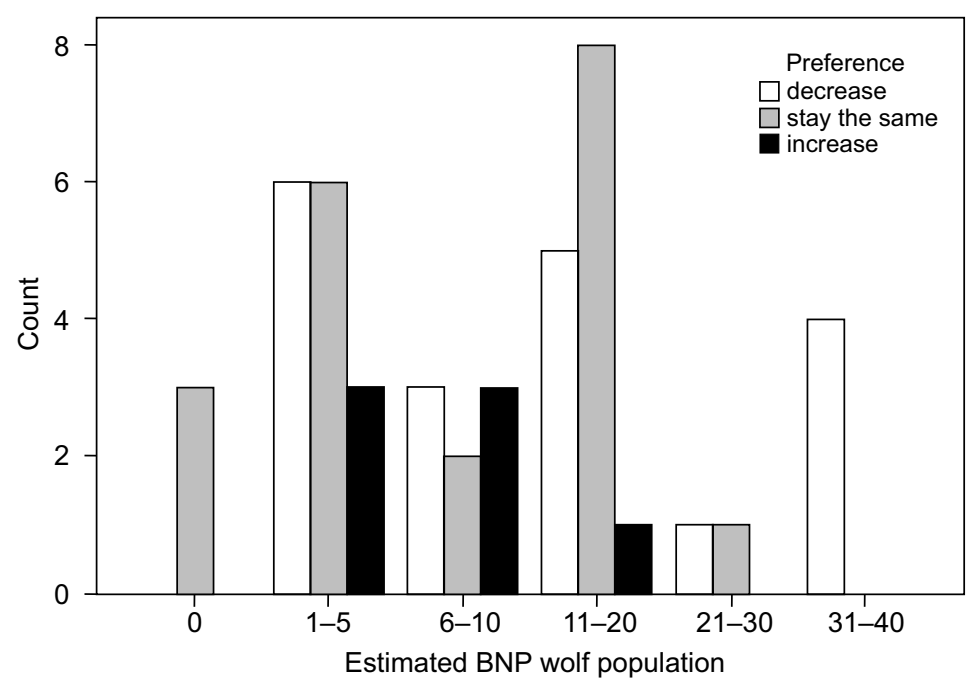

Fig. 2. Respondents' estimated BNP wolf population and preference for future population $(\mathrm{n}=48)$ 
around 4-5, which was the highest class frequency of our respondents' estimates (32.6\%; Fig. 2). Most people (50\%) desired that the wolf numbers would decrease (or remain at zero), $79.2 \%$ of which even if they estimated the current wolf numbers to be $\leq 20$. In contrast, $35.4 \%$ of respondents would prefer that the number not change, whilst only $14.6 \%$ would prefer an increase. A number of respondents who held favourable opinions towards wolves indicated their role in ecosystem structure and maintenance, and that attacks on people are unfounded.

"Wolves are removing the weaker/sick animals. Humans do harm to nature. Wolves do not attack humans, but bears do." / retired male, Szilvásvárad /

"There are so many wild boars, but the wolves chase them away. Wolves control their population, and eat dead animals. Wolves are dangerous only if they come to the village" / retired male, Nagyvisnyó /

When respondents were asked 'Who is responsible for wolf management?', 45.1\% indicated 'Forestry/Hunting company', 40.8\% answered 'BNP Directorate', whilst two people chose 'Hungarian Nature Protection Agen$\mathrm{cy}^{\prime}$ (fictional), and four did not know. The results show that residents are split regarding the question whether wolf management is a nature protection or a forestry/wild game management issue. Five respondents remarked that wolves were deliberately introduced into BNP, with some claiming they know who introduced them.

Wolves were introduced by someone, this is 100\% sure. The Bükk is too small for wolves, and wolves are not indigenous here. / retired female, Répáshuta /

Wolves were introduced deliberately, to keep the ecosystem healthier (to kill weak and sick prey) but now the wolf eats everything - I know exactly by whom they were introduced, but I am not allowed to tell it, but I know it for sure. / female pensioner, Nagyvisnyó /

Several others noted that although there is a system of compensation for wolf damage, it is inefficient, and not worth initiating the procedure, because the authorities 'will not assign any compensation'. Both interviewed livestock owners, whose animals suffered wolf attacks, expressed their disappointment in wolf management and the handling of their cases, including promises of provision of electric fencing which never materialized.

Finally, respondents were provided with 14 statements to assess attitudes towards wolves and their management at BNP. Respondent attitudes were varied, with a wide range of negative, neutral and positive responses, and scores ranging from 2.00-4.63 (Table 2).

Three items were removed $(10,12,14)$ to increase scale reliability resulting in a Cronbach's alpha value of 0.87, with a total of 11 items. Converted scores indicating attitude direction resulted in Wolf Attitude Index (WAI) values ranging from -20 to $22(\mathrm{M}=0.59, \mathrm{SD}=10.874, \mathrm{n}=51$; Fig. 3$)$. One-third of all respondents had neutral scores ranging from -6.68 to 6.00 . 
Table 2. Mean response attitude scores on statements concerning wolves and their management at BNP (ranges from $1=$ very negative to $5=$ very positive). Italicized items represent those requiring reversed scoring (see Methods).

\begin{tabular}{llcc}
\hline & Item & Mean & SD \\
\hline 1 & $\begin{array}{l}\text { I only accept the presence of wolves if there would be some finan- } \\
\text { cial profit from them (e.g. fur sales) }\end{array}$ & 4.63 & 1.113 \\
2 & Wolves are part of the beauty and wonder of nature. & 3.55 & 1.591 \\
3 & Wolves should be protected so future generations can get to know them. & 3.43 & 1.603 \\
4 & Wolves are ruthless, dangerous killers. & 3.37 & 1.536 \\
5 & Wolves can attack children. & 3.24 & 1.518 \\
6 & Wolves pose a threat to the safety of hikers. & 3.12 & 1.558 \\
7 & Wolves pose a threat to livestock safety. & 2.69 & 1.568 \\
8 & Wolves cause damage. & 2.57 & 1.432 \\
9 & Wolves decimate wild game and thus cause damage. & 2.53 & 1.528 \\
10 & Wolves are an important part of nature. & 2.45 & 1.487 \\
11 & It should not be allowed that wolves populate the Bükk Hills. & 2.31 & 1.503 \\
12 & Wolves pose a threat to residents' safety. & 2.25 & 1.481 \\
13 & I would be happy if the BNP wolf population would increase. & 2.16 & 1.362 \\
14 & Wild boar cause a lot of damage. & 2.00 & 1.456 \\
\hline
\end{tabular}

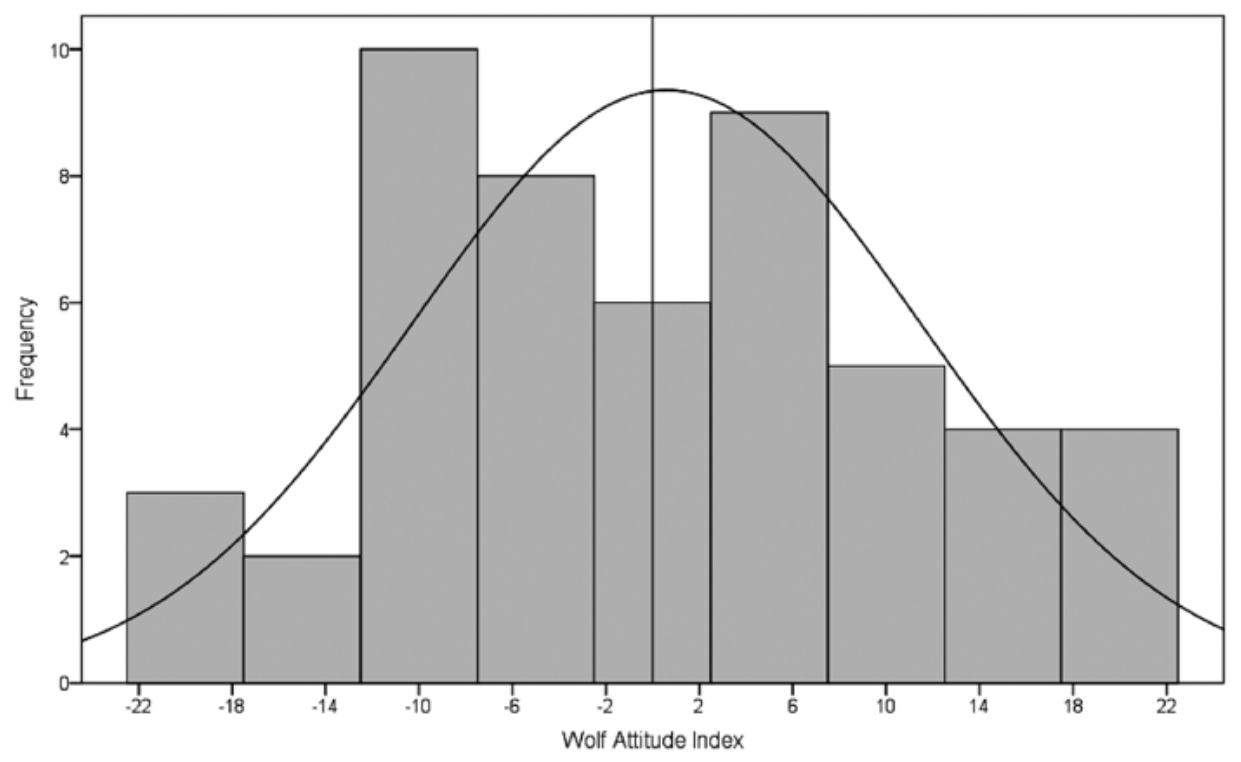

Fig. 3. Frequency and distribution of index scores towards wolves and their management at $\mathrm{BNP}(-22$ = strongly negative; 22 = strongly positive $)$ 
We tested for correlation between WAI scores and our captured sociodemographic, BNPD relationship, and wolf knowledge and experience variables. Correlation analysis identified 11 factors significantly correlated with WAI scores. Stepwise elimination of factors due to collinearity and model contribution resulted in only two factors significantly contributing to the model (hunt, infofamilyfriend). A two-way Factorial ANOVA was conducted to compare the main effects of these two factors, and their interaction effect, on WAI score. Both factors involved two levels (yes, no), and were found to be statistically significant at the .05 significance level. The main effect for hunt yielded an $\mathrm{F}$ ratio of $F(1,47)=5.376, p<0.05$, indicating a significant difference between those who hunt $(\mathrm{M}=9.33, \mathrm{SD}=11.676)$ and those who do not $(\mathrm{M}=0.04, \mathrm{SD}=$ 10.715). Moreover, the main effect for infofamilyfriend yielded an $\mathrm{F}$ ratio of $F(1,47)=5.224, p<0.05$, indicating a significant difference between those who gain knowledge regarding wolves from family or close friends $(\mathrm{M}=-5.44$, $\mathrm{SD}=9.508)$ and those who do not $(\mathrm{M}=3.34, \mathrm{SD}=10.446)$. The interaction effect was non-significant, $F(1,47)=0.591, p>0.05$.

\section{DISCUSSION}

Most of the mixed results found are aligned with other studies focusing on human-wolf (TREves et al. 2013) and park-people relationships in rural settings (Anthony 2007). In a rural area where a once extirpated large carnivore re-enters, local attitudes can be negative (LinNeLl 2013), although many of our respondents held more neutral attitudes. This may be explained by the relatively small numbers of wolves in BNP, low frequency of personal (negative) encounters, and the relatively short time frame since their appearance ( $<7$ years). Expanding the sample size and spatial scope of survey respondents would assist in determining the full breadth of attitudes towards wolves in the BNP vicinity.

Our respondents presented largely rational explanations and reasoning regarding their negative attitudes, which were concentrated around the concept of material damage caused by wolves (items 7-9, Table 2), and not by fear (items 4-6, Table 2). At the same time, this result assumes that the perception of the risk of damage that wolves cause might be greater than the actual damage, which is often manifested in human-wolf conflicts (Anthony \& Szabo 2011, Hojberg et al. 2016, Linnell 2013). The negligible role of fear is somewhat contrary to expectations based on the general phenomenon that fear of wolves attacking humans is exaggerated, especially in areas where the wolf re-appeared after a long period of absence (LinNell et al. 2002, LinNell 2013). Again, a wider analysis would help explicate these initial findings concerning perceived and real risks associated with wolves. 
Many respondents, even those with the lowest wolf-tolerance, presented more positive attitudes regarding the concept of attributing intrinsic or aesthetic value to wolves (items 1-3, Table 2). Consequently, we can assume that in terms of values, anthropocentrism may be less common amongst our respondents than expected (Lute et al. 2016). Our respondents do value wolves per se; their concern is the territory of BNP being inadequate (too small and/ or close to human activities/settlements) for wolf populations. Therefore, residents are likely to be unaware that at high biomass density, wolves can adapt to relatively small territories in the proximity of humans (Kojola et al. 2016, Sillero-Zubiri et al. 2004). The fact that recreation is the most frequent purpose to visit BNP also suggests that non-utilitarian values regarding nature is substantial amongst our respondents, i.e. they value their natural environment for its potential to provide aesthetic/recreational services. In addition, several respondents commented about wolves' role in the ecosystem in terms of controlling prey populations - although this was not quantitatively assessed - which is also a common trend in human-wolf relations (Месн 2017). In summary, extremely negative and irrational feelings and fear is uncommon amongst our sample, and local wolf conservation has sufficient moral foundations - in parallel with European and North American tendencies - of increasing cultural support of large carnivore conservation (LiNNELL 2013).

Females, older people, and people with lower level of education did not demonstrate more negative attitudes that have been found elsewhere in different contexts (Hojberg et al. 2016, Naughton-Treves et al. 2003, РонjaMүкRA \& Kurкi 2014). However, given that our study was a trial, these relationships should be explored further and complemented with more in-depth questioning utilizing e.g. focus groups.

Several respondents signalled that their knowledge about wolves derives primarily from television, but other media and communication products were also mentioned. Interestingly, those who relied on wolf knowledge from family or close friends were more likely to hold negative attitudes towards wolves. Therefore, we suggest that the responsibility of media is high in shaping people's knowledge and attitudes towards large carnivores and wildlife in general (AlLEN et al. 2017) and certainly may assist in dispelling current negative beliefs. The common phenomenon of misinformation and rumours regarding large carnivores and the risks and damage they pose is apparent in the area, confirmed by the common belief among respondents that wolves were deliberately introduced into the park.

The root causes of human-wolf conflict in BNP are likely found in socio-economic and cultural factors, parallel to the common phenomenon that wolves are often referred to as symbols for several other problems (LinNelL et al. 2002, Linnell 2013, Месн 2017). Both questionnaire respondents and 
other stakeholders expressed their concern about the economic effects of decreasing hunting revenues, and a concomitant reduction in the demand of related services (seasonal jobs at hunts, accommodation and catering). However, the causal link between wolves and declining wild game populations has not been established, in fact some research has demonstrated that even under strong predation pressure deer populations can remain stable (LANSZKI et al. 2012), and is probably the alteration of wild game behaviour that wolf presence triggers (LinNELL 2013). Thus, wolves might alter the behaviour of wild game, which can challenge existing hunting practices. The fact that a significant positive effect was found between survey respondents who hunt in BNP and level of acceptance was unexpected, and runs contrary to previous studies (Dressel et al. 2015, Месн 2017). On one hand, this may confirm the relationship between education and attitudes (WECHSELBERGER et al. 2005), as those who hunt are likely to have more intimate knowledge of wildlife. However, anti-wolf sentiment within the hunting community likely persists, as wolf shooting was standard protocol just a few decades ago (SzEDERJer \& RónA 1967), and both our interviewed wild game manager and BNPD employee indicated this antagonistic sentiment. The negative attitudes are intensified by the tendency of strong group pressure within the hunting community. As hunting is an expensive activity, attracting politically or economically influential people, the participation of hunters as key stakeholders in wolf conservation is desirable (РонJA-MyкRa \& KurKi 2014). A follow-up study focusing on a wider representation of relevant stakeholders would help to tease out these nuances which we have brought to light.

Frustrations about nature conservation practices and its economic and psychological consequences are also important factors in the development of negative attitudes towards wolves and wolf management, symbolizing local residents' feelings of powerlessness and exposure towards a centrally controlled authority (LinNELL 2013, Lute et al. 2016). Respondents expressed their dissatisfaction about these items in relation with the wolf issue impulsively, even if the questionnaire did not contain this concept at all. In the Bükk region, historically, the extraction of natural resources (firewood, timber, charcoal, limestone, etc.) were major sources of local economy (Veres 2003). In the last couple of decades, due to national and EU policies and decisions - reflecting the general public's increasingly pro-conservation attitudes - nature conservation and protected area management has transformed, and obtained a higher priority (Linnell 2013, Natura 2000 2013). The introduction and expansion of modern, sustainable forestry practices (e.g. leaving dead wood material in the forest, logging selected trees instead of clear-cutting whole territories) (BNPD 2017b) can cause disappointment in local residents, who were socialized with the idea of human control and extensive cultivation of the forest. Also, the ban of collecting firewood and other resources from protected 
areas, or entering BNP by car, was not strictly enforced until the last 10-15 years. With stricter rules and enforcement, people could have the perception that they lost control against outside authorities, and are now deprived of precious resources they believe to be legal (e.g. firewood, mushrooms). This disappointment can influence attitudes towards wolves, especially if the appearance of wolves roughly corresponds to the beginning of novel nature conservation practices or the stricter enforcement of nature protection laws. The stubborn belief among several respondents that wolves were deliberately introduced by BNPD is further evidence for this tension, as was the disappointment of the livestock owners about wolf management and the lack of trust towards authorities.

In the past 25 years, job opportunities are decreasing in the region, and depopulation is significant (KSH 2017a, 2017b). The desperation in experiencing a declining economy and a shrinking community may also explain negative wolf attitudes because of the perception of receiving less attention and financial resources than wildlife, i.e. being under-prioritized with respect to nature conservation - and its symbolic species, the wolf. Some respondents mentioned in a bitter tone, that wolves and nature protection seem to be more important than humans.

\section{CONCLUSION}

Attitudes towards wolves and wolf management from our study respondents are mixed, with a significant portion being neutral. Wolf presence is not considered as a highly important local matter. On one hand, respondents show tendencies of negative attitudes typical of regions where the wolf returned after a long absence. Yet, due to the prevalence of attributing intrinsic/aesthetic values to wolves, wolf conservation has sufficient moral foundations within local residents. The role of media (mostly television) and rumours are important sources of information about wolves and wolf management, which can lead to misinformation, such as the common belief that wolves were introduced deliberately to BNP.

The origins of human-wolf conflicts in BNP are largely rooted in socioeconomic factors, and other changes in the wider context, of which wolves are interpreted as symbols. Decreasing hunting revenue and its impact on other sectors is an important concern. Rural depopulation and the lack of permanent job opportunities can lead to the association of wolves with other nature protection practices, which restrict employment (less seasonal jobs) or natural resource use possibilities (enforcement of regulation on firewood collection).

One of the core lessons learned from human-wildlife conflict studies elsewhere is the potential danger in generalizing findings from one study and 
applying them in other contexts. Cases differ between countries, and even between species within countries, highlighting that conservation conflicts can produce very nuanced and mixed perceptions. In light of this limitation, however, our findings do have noteworthy relevance and resonance beyond our sample. First we recommend that a follow-up study be conducted which would see an expansion of the sampling frame to all villages within/adjacent to BNP, and a broader representation across (and within) relevant stakeholders inter alia the forestry and hunting communities, NGOs, and local municipalities. In addition, based on our initial findings, we suggest recommendations for wolf management in BNP, and for similar contexts elsewhere.

Active, evidence-based communication: misguided beliefs and misconceptions are often common in human-wolf conflicts. The active communication of evidence-based information on human-wolf matters e.g. in our case such as why BNP is suitable wolf habitat, or its true impact on wild game populations, can gain trust in the local public and improve local attitudes.

Communication enforcing the intrinsic/aesthetic values of wolves: At $\mathrm{BNP}$, residents already attribute positive attitudes towards the intrinsic values of wolves. The reinforcement of this concept where present can further strengthen positive attitudes and stimulate expansion of positive attitudes towards other pro-conservation concepts.

Consistent, fair and straightforward compensation of wolf damages: Livestock owners who suffered damage expressed their disappointment about not receiving promised compensation. Clear rules about conditions of compensation and their consistent enforcement is necessary in gaining trust and cooperation in the most impacted stakeholder group.

Modelling of wolf populations and their impact and its communication: particularly in relatively small protected areas at the edge of species' ranges (such as BNP), it is necessary to determine ideal, sustainable wolf population sizes. The modelling of several scenarios and population sizes should be analysed, and related wolf-management practices developed. The preparation and communication of careful planning can improve the confidence and attitudes of residents, and other stakeholders.

Acknowledgements - We thank CEU for funding and all research participants who gave of their time for this study. We also thank Eszter Kovács, two anonymous reviewers, and the Editor for reviewing earlier versions of this manuscript. Lastly, we thank Anastasia Kvasha for assistance with Figure 1. 


\section{REFERENCES}

Allen, B. L., Allen, L. R., Andrén, H., Ballard, G., Boitani, L., Engeman, R. M. \& Parker, D. M. (2017): Can we save large carnivores without losing large carnivore science? Food Webs 12: 64-75. https://doi.org/10.1016/j.fooweb.2017.02.008

Anon (2017): A város története. [History of the town.]. - Retrieved from http://belapatfalva .hu/index.php/a-varos-tortenete.html.

Anthony, B. (2007): The dual nature of parks: attitudes of neighbouring communities towards Kruger National Park, South Africa. - Environmental Conservation 34(3): 236245. https://doi.org/10.1017/s0376892907004018

Anthony, B. \& Szabo, A. (2011): Protected areas: Conservation cornerstones or paradoxes? Insights from human-wildlife conflicts in Africa and southeastern Europe. Pp. 255282. In: LóPEz-PujoL, J. (ed.): The importance of biological interactions in the study of biodiversity. - InTech Publications, Rijeka, Croatia. https://doi.org/10.5772/23047

BArкham, P. (2017): Denmark gets its first wild wolf pack in 200 years. - The Guardian [online]. https://www.theguardian.com/environment/2017/may/04/denmark-gets-its -first-wild-wolf-pack-in-200-years

BoITANI, L. (1995): Ecological and cultural diversities in the evolution of wolf-human relationships. Pp. 3-12. In: Carbyn, L. N., Fritts, S. H. \& SeIP, D. R. (eds): Ecology and conservation of wolves in a changing world. - Canadian Circumpolar Institute, Edmonton.

Bükk National Park Directorate (BNPD) (2011): Jelentés a Bükki Nemzeti Park Igazgatóság 2010. évi tevékenységéról. [Annual report on Bükk National Park Directorate's Activities, 2010]. - Retrieved from http://regi.bnpi.hu/oldal/tervek-jelentesek-309.html

Bükk National Park Directorate (BNPD) (2014): Jelentés a Bükki Nemzeti Park Igazgatóság 2013. évi tevékenységéröl. [Annual report on Bükk National Park Directorate's Activities, 2013]. - Retrieved from http://regi.bnpi.hu/oldal/tervek-jelentesek-309.html

Bükk National Park Directorate (BNPD) (2015): Jelentés a Bükki Nemzeti Park Igazgatóság 2014. évi tevékenységéröl. [Annual report on Bükk National Park Directorate's Activities, 2014]. - Retrieved from http://regi.bnpi.hu/oldal/tervek-jelentesek-309.html

Büкk National Park Directorate (BNPD) (2016): Jelentés a Bükki Nemzeti Park Igazgatóság 2015. évi tevékenységéről. [Annual report on Bükk National Park Directorate's Activities, 2015]. - Retrieved from http://regi.bnpi.hu/oldal/tervek-jelentesek-309.html

Bükk National Park Directorate (BNPD) (2017a): Foundation of the Bükk National Park. - Retrieved from http://en.bnpi.hu/oldal/fundation-of-the-bukk-national-park-11 .html.

Bükk National Park Directorate (BNPD) (2017b): A Bükki Nemzeti Park erdei. [Forests of Bükk National Park]. - Retrieved from https://bnpi.hu/oldal/a-bukki-nemzeti-park -erdei-45.html.

Chapron, G., Kaczensky, P., Linnell, J. D. C., von Arx, M., Huber, D., Andrén, H. et al. \& BoITANI, L. (2014): Recovery of large carnivores in Europe's modern human-dominated landscapes. - Science 346(6216):1517-1519. https://doi.org/10.1126/science.1257553

Clark, K. E., Cupp, K., Phelps, C. L., Peterson, M. N., Stevenson, K. T. \& Serenari, C. (2017): Household dynamics of wildlife value orientations. - Human Dimensions of Wildlife 22(5): 483-491. https://doi.org/10.1080/10871209.2017.1345022

Своnвасн, L. J. (1951): Coefficient alpha and the internal structure of tests. - Psychometrika 16(3): 297-334. https://doi.org/10.1007/bf02310555

Dalerum, F., Cameron, E. Z., Kunkel, K. \& Somers, M. J. (2009): Diversity and depletions in continental carnivore guilds: implications for prioritizing global carnivore conservation. - Biology Letters 5(1): 35-38. https://doi.org/10.1098/rsbl.2008.0520 
Dressel, S., Sandström, C. \& Ericsson, G. (2015): A meta-analysis of studies on attitudes toward bears and wolves across Europe 1976-2012. - Conservation Biology 29(2): 565574. https://doi.org/10.1111/cobi.12420

Fernández-Gil, A., Naves, J., Ordiz, A., Quevedo, M., Revilla, E. \& Delibes, M. (2016): Conflict misleads large carnivore management and conservation: Brown bears and wolves in Spain. - PLOS ONE 11(3): e0151541. https://doi.org/10.1371/journal.pone .0151541

Flick, U., von Kardorff, E. \& Steinke, I. (eds) (2010): A companion to qualitative research. SAGE, London, $448 \mathrm{pp}$.

Fritts, S. H., Stephenson, R. O., Hayes, R. D. \& Boitani, L. (2003): Wolves and humans. Pp. 289-317. In: Месн, L. D. \& Boitani, L. (eds): Wolves: Behavior, ecology, and conservation. - University of Chicago Press, Chicago.

Heberlein, T. A. (2012): Navigating environmental attitudes. - Oxford University Press, Oxford, 240 pp. https://doi.org/10.1093/acprof:oso/9780199773329.001.0001

Heltai, M. (2002): Status and distribution of carnivores in Hungary. PhD Dissertation. - Szent István University, Gödöllő, Hungary. Retrieved from http://www.vmi.szie.hu /kutatas/HM/carnivoresstatus_english_HM.pdf

Herzog, S. (2018): Return of grey wolf (Canis lupus) to Central Europe: challenges and recommendations for future management in cultural landscapes. - Annals of Forest Research 61(2): 203-209. https://doi.org/10.15287/afr.2018.1190

Hojberg, P. L., Nielsen, M. R. \& Jacobsen, J. B. (2016): Fear, economic consequences, hunting competition, and distrust of authorities determine preferences for illegal lethal actions against gray wolves (Canis lupus): A choice experiment among landowners in Jutland, Denmark. - Crime, Law and Social Change 67(4): 461-480. https://doi.org/10 .1007/s10611-016-9670-2

IBM CoRp. (2013): IBM SPSS Statistics for Windows, Version 22.0. - IBM Corp., Armonk, NY.

Johansson, M. \& Karlsson, J. (2011): Subjective experience of fear and the cognitive interpretation of large carnivores. - Human Dimensions of Wildlife 16(1): 15-29. https://doi .org/10.1080/10871209.2011.535240

Kaczensky, P., Chapron, G., von Arx, M., Huber, D., Andrén, H. \& Linnell, J. (2013): Status, management and distribution of large carnivores - bear, lynx, wolf $\mathcal{E}$ wolverine - in Europe. Part 1. Europe summaries. Report: 1-72. A Large Carnivore Initiative for Europe Report prepared for the European Commission. - Retrieved from https://www.europarc.org/wp-content /uploads/2017/02/Kaczensky_et_al_2013_Status_management_and_distribution_of _large_carnivores_in_Europe_1.pdf

Kojola, I., Hallikainen, V., Mikkola, K., Gurarie, E., Heikkinen, S., Kaartinen, S., NiKula, A. \& Nivala, V. (2016): Wolf visitations close to human residences in Finland: The role of age, residence density, and time of day. - Biological Conservation 198: 9-14. https://doi.org/10.1016/j.biocon.2016.03.025

Központi Statisztikai Hivatal (KSH) (2016): Fókuszban a megyék [Focus on the counties]. Retrieved from http://www.ksh.hu/docs/hun/xftp/megy/164/index.html.

Központi Statisztikai Hivatal (KSH) (2017a): Területi adatok-Borsod-Abaúj-Zemplén megye [Regional Data, Borsod-Abaúj-Zemplén County]. - Retrieved from http://www.ksh .hu/nepszamlalas/tablak_teruleti_05

Központi Statisztikai Hivatal (KSH) (2017b): Területi adatok - Heves megye [Regional Data, Heves County]. - Retrieved from http://www.ksh.hu/nepszamlalas/tablak_teruleti -10.

KrippendorfF, K. (2004): Content analysis: An introduction to its methodology. 2nd ed. - SAGE, Thousand Oaks, CA, 440 pp. 
Lanszki, J., Márkus, M., Újváry, D., Szabó, A. \& Szemethy, L. (2012): Diet of wolves Canis lupus returning to Hungary. - Acta Theriologica 57(2): 189-193. https://doi.org/10.1007 /s13364-011-0063-8

Large Carnivore Initiative for Europe (LCIE) (2019): Wolf - Canis lupus. - http://www .lcie.org/Large-carnivores/Wolf-

Lescureux, N. \& Linnell, J. D. C. (2014): Warring brothers: The complex interactions between wolves (Canis lupus) and dogs (Canis familiaris) in a conservation context. Biological Conservation 171: 232-245. https://doi.org/10.1016/j.biocon.2014.01.032

Linnell, J. D. C., Reidar, A., Andersone, Z., Balciauskas, L., Blanco, J. C., Boitani, L., Brainerd, S., Beitenmoser, U., Kojola, I., Liberg, O., Løe, J., Okarma, H., Pedersen, H. C., Promberger, C., Sand, H., Solberg, E. J., Valdmann, H. \& Wabakken, P. (2002): The fear of wolves: A review of wolf attacks on humans. - NINA - Oppdragsmelding 731: 1-65.

LinNELL, J. D. C. (2013): From conflict to coexistence? Insights from multi-disciplinary research into the relationships between people, large carnivores and institutions. - European Commission, Brussels, 56 pp.

Lute, M. L., Navarrete, C. D., Nelson, M. P. \& Gore, M. L. (2016): Moral dimensions of human-wildlife conflict. - Conservation Biology 30(6): 1200-1211. https://doi.org/10 .1111/cobi.12731

Mattson, D. J. (2004): Living with fierce creatures? An overview and models of mammalian carnivore conservation. Pp. 151-176. In: Fascione, N., Delach, A. \& Smith, M. E. (eds): People and predators: From conflict to coexistence. - Island Press, Washington DC.

Mech, L. D. (2017): Where can wolves live and how can we live with them? - Biological Conservation 210A: 310-317. https://doi.org/10.1016/j.biocon.2017.04.029

Mech, D. \& Boitani, L. (2003): Wolves: behavior, ecology, and conservation. - University of Chicago Press, Chicago, 472 pp. https://doi.org/10.7208/chicago/9780226516981.001 .0001

Mech, L. D., \& Boitani, L. (IUCN SSC Wolf Specialist Group) (2010): Canis lupus. - The IUCN Red List of Threatened Species 2010: e.T3746A10049204. Retrieved from http:// www.iucnredlist.org/details/3746/0.

Minók, B., Biró, M., Molnár, Zs., Kovács, E., BölöNi, J., Erôs, T., Standovár, T., TöröK, P., Csorba, G., MArgóczi, K. \& BÁLdI, A. (2017): Biodiversity on the waves of history: Conservation in a changing social and institutional environment in Hungary, a postsoviet EU member state. - Biological Conservation 211A: 67-75. https://doi.org/10.1016 /j.biocon.2017.05.005

Natura 2000 (2013): Országos Natura 2000 priorizált intézkedési terv a 2014-2020 EU többéves pénzügyi idöszakra. [National Natura 2000 prioritized action plan for the EU's financial period between 2014-2020]. - Retrieved from http://www.termeszetvedelem.hu/ _user/browser/File/Natura2000/PAF/PAF_kivonat_\%20Magyar.pdf

Naughton-Treves, L., Grossberg, R. \& Treves, A. (2003): Paying for tolerance: Rural citizens' attitudes toward wolf depredation and compensation. - Conservation Biology 17(6): 1500-1511. https://doi.org/10.1111/j.1523-1739.2003.00060.x

Pohja-Myкra, M. \& Kurki, S. (2014): Strong community support for illegal killing challenges wolf management. - European Journal of Wildlife Research 60(5): 759-770. https://doi .org/10.1007/s10344-014-0845-9

PRIMM, S. A. \& CLARK, T. W. (1996): Making sense of the policy process for carnivore conservation. - Conservation Biology 10(4): 1036-1045. https://doi.org/10.1046/j.1523-1739 .1996.10041036.x 
Rigg, R., Findo, S., Wechselberger, M., Gorman, M. L., Sillero-Zubiri, C. \& Macdonald, D. W. (2011): Mitigating carnivore-livestock conflict in Europe: Lessons from Slovakia. - Oryx 45(2): 272-280. https://doi.org/10.1017/s0030605310000074

Roaf, J., Atoyan, R., Joshi, B. \& Krogulski, K. (2014): 25 years of transition: Post-communist Europe and the IMF. - Regional Economic Issues Special Report. IMF, Washington, DC., 62 pp.

Russo, C., Mattiello, S., Bibbiani, C., Baglini, A., Bongi, P., \& Facchini, C. (2016): Impact of wolf (Canis lupus) on animal husbandry in an Apennine Province. - Italian Journal of Animal Science 13(3): 3303. https://doi.org/10.4081/ijas.2014.3303

Schutт, R. K. (2016): Sampling and generalizability. Pp. 91-110. In: Chambliss, D. F. \& Schutт, R. K. (eds): Making sense of the social world: Methods of investigation. 5th ed. SAGE, Thousand Oaks, CA

Sillero-Zubiri, C., Hoffmann, M. \& MacDonald, D. W. (eds) (2004): Canids: Foxes, wolves, jackals, and dogs. Status survey and conservation action plan. - IUCN/SSC Canid Specialist Group. IUCN, Gland, Switzerland and Cambridge, UK, 430 pp.

Skogen, K. \& Krange, O. (2003): A wolf at the gate: The anti-carnivore alliance and the symbolic construction of community. - Sociologia Ruralis 43(3): 309-325. https://doi .org/10.1111/1467-9523.00247

SzEDeRJEI, Á., \& RónA, I. (1967): Mit kell tudni a vadászsportról? Segédkönyv a vadászvizsgához. [What is there to know about recreational hunting? Aid for the preparation to the hunting exam]. - Sport, Budapest, 179 pp.

Szemethy, L., Firmánszky, G., Heltai, M., Szabó, Á. \& Márkus, M. (2004): Farkas (Canis lupus) fajmegórzési terv. [Action Plan for Wolf (Canis lupus)]. - Ministry of Environment and Water, Hungary, Budapest.

Treves, A., Naughton-Treves, L. \& Shelley, V. (2013): Longitudinal analysis of attitudes toward wolves. - Conservation Biology 27(2): 315-323. https://doi.org/10.1111/cobi .12009

Veres, L. (2003): A Bükk hegység hutatelepülései. [Glass producing villages of the Bükk Mountains]. - Borsod-Abaúj-Zemplén Megyei Levéltár és a Borsod-Abaúj-Zemplén Megyi Múzeumi Igazgatóság, Miskolc.

Wechselberger, M., Rigg, R. \& Betková, S. (2005): An investigation of public opinion about the three species of large carnivores in Slovakia: brown bear (Ursus arctos), wolf (Canis lupus) and lynx (Lynx lynx). - Slovak Wildlife Society, Liptovský Hrádok.

Zumbo, B. D. \& Zimmerman, D. W. (1993): Is the selection of statistical methods governed by level of measurement? - Canadian Psychology 34(4): 390-400. https://doi.org/10 $.1037 / \mathrm{h} 0078865$

Received January 30, 2019, accepted April 16, 2019, published May 31, 2019 